\title{
Descriptive Study of Efforts Integrates Character Values to Students
}

\author{
Sultoni \\ Department of Educational Administration \\ State University of Malang, Indonesia \\ sultoni.fip@um.ac.id
}

\author{
Imam Gunawan \\ Department of Educational Administration \\ State University of Malang, Indonesia \\ imam.gunawan.fip@um.ac.id
}

\author{
Sari Oktavia Ningsih \\ Department of Educational Administration \\ State University of Malang, Indonesia \\ oktavias237@gmail.com
}

\begin{abstract}
The purpose of this research is to describe the level of internalization of student character values. The approach used in this research is to use a quantitative approach. The sample was 46 students. Sampling technique in this research is quota random sampling. Closed questionnaire is a research instrument that is used to measure the internalization level of student character values. Analysis of research data using descriptive statistics. The results of the calculation of the score data shows that the average score of 60.28 and the standard deviation of 7.21. The result of descriptive analysis concluded that the level of internalization of student character values with the average of 60.28 included in the category is quite good.
\end{abstract}

Keywords: internalization, character, student

\section{INTRODUCTION}

The study of current character is often covered in seminars or in theoretical studies. Characters contain the components of knowledge, awareness, willingness, and action to carry out a value. Therefore, there should be an effort to internalize the character to the students. Character education aims to form a nation that is strong, competitive, noble, moral, tolerant, mutually cooperative, spirited patriotic, dynamic, scienceoriented and technologically all animated by faith and piety to God Almighty based on Pancasila (Suryantini, 2011 ; Kusumaningrum, et al., 2017; Gunawan, 2015).

The process of characterizing internalization will be influenced by personality and psychological factors of a person (Margetić, et al., 2010; Agans, et al., 2018). The various characters that should be internalized within the students are honesty, humility, and personal good (Kim and Cohen, 2015; Cohen and Morse, 2014). In addition, the character that must be developed within the students is religious, honest, tolerance, discipline, hard work, creative, independent, democratic, curiosity, spirit of nationality, love of the homeland, appreciate achievement, friendly / communicative, love peace, reading, environmental care, social care, and responsibility (Kemendiknas, 2010; Kusumaningrum, et al., 2017; Gunawan, 2017a).

Characterization can be done in various ways, such as character education seminars and also the implementation of character education in educational institutions. Character education can not be separated from the social, cultural, and community environment. Character education should also be well integrated into the learning activities in the classroom. Cheung and Lee (2010) affirmed that student involvement in character education is an integral part of their learning from education. Therefore, character education for students is in need of characters, people who can be role models by students in behaving. Lecturers in this case should be a role model for students.

\section{METHODS}

This research is conducted by quantitative method. The sample of the study was 46 students from a population of 50 students attending the Winner: Character for Success training. The trainees are students who are assigned and financed by the Local Government of Kayong Utara Regency of West Kalimantan Province to study at State University of Malang (UM). The training was held on Saturday 10 February 2018 at State University of Malang. Sampling technique in this research is quota random sampling. The research instrument used is a closed questionnaire.

Indicators measured from the internalization variable of student character values are: religious, honest, tolerance, discipline, hard work, creative, independent, democratic, curiosity, spirit of nationality, love of the country, appreciate achievement, friendly / communicative, love peace, reading, environmental care, social care, and responsibility (Kemendiknas, 2010; Kusumaningrum, et al., 2017; Gunawan, 2017a). Research data is analyzed by using descriptive statistic that calculate the mean and standard deviation (Gunawan, 2013; Gunawan, 2016b; Gunawan, 2016a). Furthermore, to determine the level of internalization of student character values using a stanfive formula that matches the average with the score interval in the range of categories, namely: very good, good, quite good, less good, or not good.

\section{RESULTS}

Table 1 is the score data of internalization variable of student character values. Based on Table 1, it is known that: a minimum score of 44 ; maximum score of 72; average of 60.28; and a standard deviation of 7.21. Based on the data in Table 1 , then the variable data internalization of student character values is described with the formula formula stanfive. Table 2 presents the variable frequency description data of internalization of student character values. 
Table 1

Score Data Variable Internalisasi Values Student Character

\begin{tabular}{cccccccccc}
\hline No & Score & No & Score & No & Score & No & Score & No & Score \\
\hline 1 & 60 & 11 & 61 & 21 & 53 & 31 & 61 & 41 & 62 \\
2 & 69 & 12 & 64 & 22 & 66 & 32 & 70 & 42 & 61 \\
3 & 69 & 13 & 66 & 23 & 60 & 33 & 54 & 43 & 61 \\
4 & 61 & 14 & 59 & 24 & 66 & 34 & 69 & 44 & 57 \\
5 & 53 & 15 & 66 & 25 & 61 & 35 & 52 & 45 & 66 \\
6 & 51 & 16 & 51 & 26 & 68 & 36 & 52 & 46 & 72 \\
7 & 56 & 17 & 66 & 27 & 69 & 37 & 58 & Min & 44 \\
8 & 68 & 18 & 55 & 28 & 44 & 38 & 54 & Max & 72 \\
9 & 47 & 19 & 54 & 29 & 64 & 39 & 70 & $\bar{X}$ & 60.28 \\
10 & 44 & 20 & 58 & 30 & 67 & 40 & 58 & DS & 7.21 \\
\hline
\end{tabular}

Table 2

\begin{tabular}{ccccl}
\multicolumn{5}{c}{ Description of Variable Frequency of Internalization of Student Character Values } \\
\hline No & Interval & F & \% & Category \\
\hline 1 & $>71.10$ & 1 & 2.17 & Very good \\
2 & $63.89-71.10$ & 17 & 36.96 & Good \\
3 & $56.68-63.89$ & 14 & 30.43 & Quite good \\
4 & $49.47-56.68$ & 11 & 23.91 & Less good \\
5 & $<49.47$ & 3 & 6.52 & Not good \\
\hline & Total & $\mathbf{4 6}$ & $\mathbf{1 0 0}$ & \\
\hline
\end{tabular}

Based on Table 2 it is known that of 46 respondents who are in the interval score: $>71.10$ as much as 1 person $(2.17 \%)$ with very good category; $63.89-71.10$ as many as 17 people $(36.96 \%)$ with good category; $56.68-63,89$ as many as 14 people $(30.43 \%)$ with good enough category; $49.47-56.68$ as many as 11 people (23.91\%) with the less good category; and < 49.47 as many as 3 people $(6.52 \%)$ with bad category. Based on Table 2 it can be concluded that the index of internalization of student character values with the average of 60.28 included in the category is quite good.

\section{DISCUSSION}

The results of this study concluded the index of internalization of student character values included in the category quite good. Therefore, universities need to innovate the curriculum that integrates character education in lectures. Character is one of the variables that can affect one's quality of life (Pane and Patriana, 2016; Lidyasari, 2014). A good character displayed by a person will be able to keep that person in living his life in the community. Characters can be mentioned as a person's clothes in society.

Students who have character are the people's expectations. As an academic student, students have a special position in the life of the community. Therefore, the academic ability of the students will be meaningful and good when accompanied by a good character as well. The cultivation of student character values can be done with the application of hidden curriculum in the activities of student organizations (Gunawan, 2017b; Hartini, et al., 2012). Character education is part of the education system that is important to implement. Character education is intended to meet the needs of early adolescents in strengthening social competence (Cheung and Lee, 2010).

High social competence in students can improve their ability to create a network of friends. The social relations network enhances the collaboration and sharing of student knowledge (Stevens and Nies, 2018). Student social competence is characterized by the ability to interact with others, can communicate the message, and interpret the message orally and in writing. Character values are the result of local culture and wisdom that needs to be upheld. Local wisdom as a source of contemplative character and practices to a better life (Domínguez-Rué, 2018).

\section{CONCLUSION}

Based on the data analysis, it can be concluded the index of internalization of student character values with the average of 60.28 included in the category is quite good. Character is important for every person in the life of society. Students who have character is the hope of every nation so that he can become a generation that can fill the national development in a sustainable manner. There needs to be a massive effort in shaping the character of students.

\section{REFERENCES}

[1] Agans, J. P., Su, S., and Ettekal, A. V. 2018. Peer motivational Climate and Character Development: Testing a Practitioner-Developed Youth Sport Model. Journal of Adolescence, 62, 108-115.

[2] Cheung, C., and Lee, T. 2010. Improving Social Competence Through Character Education. Evaluation and Program Planning, 33(3), 255-263.

[3] Cohen, T. R., dan Morse, L. 2014. Moral Character: What it is and What it Does. Research in Organizational Behavior, 34, 43-61.

[4] Domínguez-Rué, E. 2018. The Art of Doing Good: Aging, Creativity, and Wisdom in the Isabel Dalhousie Novels. Journal of Aging Studies, 44, 22-27.

[5] Gunawan, I. 2013. Statistika untuk Kependidikan Sekolah Dasar. Yogyakarta: Penerbit Ombak.

[6] Gunawan, I. 2015. Mengembangkan Kepemimpinan Kepala Sekolah Berbasis Nilai dan Etika. Proceeding National Seminar and International Conference Scientific Forum-Faculty of Education Department of Science Educatioin (FIP-JIP), Fakultas Ilmu 
Pendidikan Universitas Negeri Gorontalo, Gorontalo, 9 s.d. 11 September, p. 302-312.

[7] Gunawan, I. 2016a. Metode Penelitian Kuantitatif. Retrieved June 7, 2017, from http://fip.um.ac.id/wpcontent/uploads/2015/12/2_Metpen-Kuantitatif.pdf.

[8] Gunawan, I. 2016b. Pengantar Statistika Inferensial. Jakarta: Rajawali Pers.

[9] Gunawan, I. 2017a. Landasan Dasar Pendidikan. Malang: Universitas Negeri Malang, Penerbit UM Press.

[10] Gunawan, I. 2017b. Prestasi Belajar Mahasiswa Fungsionaris UKM KSR PMI Unit Universitas Negeri Malang. Ilmu Pendidikan: Jurnal Kajian Teori dan Praktik Kependidikan, 2(2), 171-177.

[11] Hartini, Gunawan, I., and Suraya, S. N. 2012. Persepsi Mahasiswa terhadap Kualitas Pelayanan Pendidikan FIP IKIP PGRI MADIUN. Jurnal Pendidikan, 18(1), 37-66.

[12] Kemendiknas. 2010. Pengembangan Pendidikan Budaya dan Karakter Bangsa. Jakarta: Pusat Kurikulum, Badan Penelitian dan Pengembangan, Kemendiknas.

[13] Kim, Y., and Cohen, T. R. 2015. Moral Character and Workplace Deviance: Recent Research and Current Trends. Current Opinion in Psychology, 6, 134-138.

[14] Kusumaningrum, D. E., Benty, D. D. N., and Gunawan, I. 2017. Manajemen Peserta Didik. Malang: Universitas Negeri Malang, Penerbit UM Press.

[15] Lidyasari, A. T. 2014. Developing PGSD Students Character through Experience Learning Theory. Procedia - Social and Behavioral Sciences, 123, 189195.

[16] Margetić, B. A., Jakovljević, M., Ivanec, D., Margetić, B., and Tošić, G. 2010. Relations of Internalized Stigma with Temperament and Character in Patients with Schizophrenia. Comprehensive Psychiatry, 51(6), 603-606.

[17] Pane, M. M., and Patriana, R. 2016. The Significance of Environmental Contents in Character Education for Quality of Life. Procedia - Social and Behavioral Sciences, 222, 244-252.

[18] Stevens, K. P., and Nies, M. A. 2018. Transforming Nursing Education in a 140-Character World: The Efficacy of Becoming Social. Journal of Professional Nursing, 34(1), 31-34.

[19] Suryantini, S. 2011. Pendidikan Karakter. Retrieved December 20, 2016, from http://skp.unair.ac.id/ repository/Guru-Indonesia/PENDIDIKAN KARAKTER_HjSriSuryantiniSPd_9275.pdf). 